\title{
Thrombopoietin regulates proliferation, apoptosis, secretory activity and intracellular messengers in porcine ovarian follicular cells: involvement of protein kinase $A$
}

\author{
A V Sirotkin, P Sanislo, H-J Schaeffer ${ }^{1}$, I Florkovičová, J Kotwica ${ }^{2}$, \\ J Bulla and L Hetényi \\ Research Institute of Animal Production, Hlohovská 2, 94992 Nitra, Slovakia \\ ${ }^{1}$ Universitäts-Frauenklinik, 50931 Köln, Germany \\ ${ }^{2}$ Institute of Animal Production and Food Research, 10-718 Olsztyn-Kortowo, Poland \\ (Requests for offprints should be addressed to A V Sirotkin; Email: sirotkin@vuzv.sk)
}

\begin{abstract}
Thrombopoietin (TPO) is known to be involved in megakariocytopoesis, but its role in the control of ovarian function is unknown. The aims of this study were to determine whether TPO can regulate the proliferation, apoptosis and secretory activity of ovarian cells, to identify possible intracellular mediators of TPO action, especially protein kinase A (PKA), and to define their interrelationships within ovarian cells. We investigated the effect of TPO treatment $(0,1,10$ or $100 \mathrm{ng} / \mathrm{ml})$ on the following characteristics of cultured porcine ovarian follicles, determined using SDS-PAGE and Western blotting, immunocytochemistry, RIA and ELISA: the expression of intracellular peptides associated with proliferation (PCNA), apoptosis (Bax), tyrosine kinase (TK, phosphotyrosine), Cdc2/p34 kinase, PKA and the transcription factor CREB-1, and the secretion of progesterone, androstenedione, estradiol-17 $\beta$, oxytocin, inhibin $A$, inhibin $\mathrm{B}$, IGF-I, transforming growth factor- $2 \beta$ (TGF-2 $\beta$ ) and IGF-binding protein 3 (IGFBP-3). The involvement of PKA-dependent pathways was examined by evaluating the effect of a PKA blocker (KT5720, $1 \mu \mathrm{g} / \mathrm{ml}$ ), either alone or in combination with TPO, on the parameters listed above.

A TPO-induced increase in expression of PCNA, Bax, PKA, TK, Cdc2/p34 and CREB was observed.

estradiol, TGF-2 $\beta$ and IGFBP-3 secretion, and to stimulate oxytocin, inhibin A, inhibin B and IGF-I secretion. Progesterone secretion was not stimulated. The PKA blocker KT5720, when given alone, reduced the expression of Bax and TGF- $2 \beta$, augmented the expression of PKA, CREB and oxytocin, but did not influence the secretion of progesterone, androstenedione, estradiol, IGFBP-3, inhibins $A$ and $B$ or IGF-I. When given together with TPO, the PKA blocker prevented or reversed the action of TPO on PKA, CREB, androstenedione, estradiol, IGFBP-3, oxytocin, but not its effect on Bax, TGF-2 $\beta$ or inhibin B. On the other hand, treatment with KT5720 augmented the effect of TPO on progesterone, inhibin A and IGF-I.

These results provide the first evidence that TPO may be a potent regulator of ovarian function (e.g. proliferation, apoptosis and the secretion of peptide hormones, steroids, growth factors and growth factor-binding protein, as well as of the expression of some intracellular messengers). Furthermore, they demonstrated the importance of PKA in controlling these functions and in mediating the effects of TPO on ovarian cells. It remains possible that other (TK- and Cdc2/p34-dependent) intracellular mechanisms are also involved in mediating TPO action on the ovary. Journal of Endocrinology (2004) 183, 595-604
\end{abstract} Furthermore, TPO was able to inhibit androstenedione,

\section{Introduction}

Thrombopoietin (TPO) is a hormone/growth factor/ cytokine which plays an important role in stimulating the differentiation of hemopoetic stem cells, megakariocytopoesis and platelet production (Wendling \& Vainchenker 1998, Alexander 1999, Drachmann et al. 1999, Matsumura et al. 2000). The presence and turnover of the mRNA for
TPO has been described in human (Furunashi et al. 1999) and hamster (Kaszubska et al. 2000, Ryll et al. 2000) ovarian cells. This is an indirect indication that TPO is involved in controlling ovarian function. The direct effects of TPO on ovarian cells have not been studied.

The intracellular mechanisms of TPO action have been investigated only in hemopoetic and sarcoma cell lines. It has been shown that the action of TPO on the proliferation 
of these cells can be mediated by the tyrosine kinase (TK; JAK/STAT)-dependent pathway, whilst its effect on cell differentiation can be mediated via MAP kinase (MAPK)and cyclin-dependent kinase (cdc2/p34)-dependent intracellular mechanisms (Wendling \& Vainchenker 1998, Alexander 1999, Drachman et al. 1999, Matsumura et al. 2000). Recently, an additional protein kinase A (PKA)dependent pathway of TPO action on megacaryocytes has been demonstrated (Sauer et al. 2001).

The aims of this study were (1) to determine whether TPO can regulate the proliferation, apoptosis and secretory activity of ovarian cells and (2) to identify the possible intracellular mediators of its action, particularly PKA. As the site of TPO action in the ovary is unknown, we examined the effects of TPO on a wide variety of ovarian substances produced by the follicular wall. We were able to measure intracellular peptides associated with proliferation (PCNA), apoptosis (Bax), TK (phosphotyrosine), Cdc2/p34, PKA and PKA-activated transcription factor (CREB-1) in cultured porcine ovarian cells. We also investigated how TPO influences the secretion of progesterone, androstenedione, estradiol, oxytocin, inhibin A, inhibin B, insulin-like growth factor-I (IGF-I), transforming growth factor- $2 \beta$ (TGF-2 $\beta$ ) and an IGFbinding protein (IGFBP-3) by these cells. The involvement of a PKA-dependent pathway in mediating TPO action was examined using a specific PKA blocker (KT5720), alone or in combination with TPO.

\section{Materials and Methods}

\section{Preparation, culture and processing of ovarian cells}

Ovaries of non-cycling Slovakian white gilts, 200 days of age, were obtained after slaughter at a local abattoir. Halves of ovarian follicles, 3-4 $\mathrm{mm}$ in diameter without visible signs of atresia, were isolated, processed and cultured for 2 days as described previously (Sirotkin et al. 1998, 2003, Makarevich et al. 2004). Follicle cultures took place in Falcon 24-well plates (Becton Dickinson, Lincoln Park, USA) at $37^{\circ} \mathrm{C}$ under $5 \% \mathrm{CO}_{2}$ in humidified air in $2 \mathrm{ml}$ serum-free Dulbecco's modified Eagle's medium (DMEM)/F-12 1:1 mixture supplemented with 1\% antibiotic-antimycotic solution (all from Sigma, St Louis, MO, USA), using three randomly selected halves per culture. In the first series of experiments (to determine the effect of TPO on intracellular substances detected using Western immunoblotting), experimental groups received 1,10 or $100 \mathrm{ng} / \mathrm{ml}$ of immunological grade recombinant human TPO (rhTPO; R \& D Systems Inc., Minneapolis, MN, USA). These concentrations of TPO $(1-10 \mathrm{ng} / \mathrm{ml})$ were previously reported in blood and culture medium (Alexander 1999, Drachman et al. 1999, Kaszubska et al. 2000, Matsumura et al. 2000, Ryll et al. 2000). Control tissues were cultured without TPO. In the second series of experiments (effects of TPO and PKA blocker on intra- cellular substances detected using immunocytochemistry and on secretion of substances measured using RIA or ELISA), follicular tissue was cultured with 1,10 or $100 \mathrm{ng} / \mathrm{ml} \mathrm{rhTPO}$, a selective PKA inhibitor, KT5820 $(1 \mu \mathrm{g} / \mathrm{ml}$; Calbiochem-Novabiochem Corp., La Jolla, CA, USA) or both of these substances. KT5720 was dissolved in $50 \mu \mathrm{l} \mathrm{DMSO}$ to a final concentration of $1 \mathrm{mg} / \mathrm{ml}$. Immediately before the experiment, these stock solutions were dissolved in incubation medium so that the content of DMSO in the medium did not exceed 0.001\%. Other substances were dissolved in medium immediately before the experiment. Control groups contained either no ovarian tissue (blank control) or tissue without exogenous TPO or inhibitor, but with or without equivalent tracer amounts of DMSO.

The isolated follicles were cultured for 2 days. It has been demonstrated previously that porcine ovarian follicles cultured in these conditions for up to 8-10 days were viable and able to grow (Sirotkin et al. 2003), as indicated by cellular proliferation which was associated with cell proliferation (Makarevich et al. 2004) and the secretion of steroid and peptide hormones (Sirotkin et al. 1998). After 2 days of culture, follicular tissues intended for gel electrophoresis and Western immunoblotting were collected and processed as described previously (Sirotkin \& Makarevich 1999) then frozen at $-18{ }^{\circ} \mathrm{C}$. After 2 days of culture, granulosa cells intended for immunocytochemical analysis were separated from the rest of the follicular wall using gentle trituration of follicular halves for $10 \mathrm{~min}$ in phosphate-buffered saline (PBS) followed by centrifugation for $10 \mathrm{~min}$ at $200 \mathrm{~g}$. They were fixed for $20 \mathrm{~min}$ in ice-cold $4 \%$ paraformaldehyde in PBS, air-dried on microscope slides and kept at $4{ }^{\circ} \mathrm{C}$ until immunocytochemical analysis. A proportion of granulosa cells were removed before centrifugation. Part of these cells was subjected to Trypan blue staining to evaluate viability; this varied between 70 and $85 \%$ and no statistically significant differences between control and experimental groups were observed. Another portion of these cells was subjected to 2 days culture in Lab-Tek chamber-slides (Nunc, Inc., Naperville, TN, USA) at a concentration of $1 \times 10^{6}$ cells $/ \mathrm{ml}$. These cells were subsequently fixed as described above to confirm the immunocytochemical data on localization of antigens in freshly isolated granulosa cells (the localization is better seen in granulosa cells expanded during culture), whilst the quantitative immunocytochemical analyses were performed on freshly isolated granulosa cells (see above). The medium conditioned by cultured ovarian follicles was gently aspirated and frozen at $-18^{\circ} \mathrm{C}$ to await RIA.

\section{Protein gel electrophoresis (SDS-PAGE) and Western immunoblotting}

Electrophoresis and Western immunoblotting of frozen follicular tissue was performed according to Laemmli (1970) 
as described previously (Sirotkin \& Makarevich 1999) using the following antisera from Santa Cruz Biotechnology, Inc. (Santa Cruz, CA, USA): (1) rabbit polyclonal antibody against the human proliferating cell nuclear antigen PCNA (cross-reacts with mouse, rat, human, insect and yeast full-length PCNA, used at a dilution of 1:100), (2) mouse monoclonal antibody against the mouse apoptosisassociated peptide Bax (binds Bax of mouse, rat and human origin; dilution 1:500), (3) rabbit polyclonal antibody against the human cyclin dependent kinase $\mathrm{Cdc} 2$ / p34 (cross-reacts with full length human, rat, mouse, chicken and yeast Cdc2/p34; dilution 1:100), (4) mouse monoclonal antibody against phosphotyrosine-containing proteins for assessment of activity of TKs (specific for phosphotyrosine, but not for phosphoserine or phosphotreonine; dilution 1:1000), (5) rabbit polyclonal antibody against the human PKA (cross-reacts with the type I $\beta$ regulatory subunit and partially with the I $\alpha$ catalytic subunit of human, mouse, rat, bovine and porcine PKA; dilution 1:1000) and (6) rabbit polyclonal antibody against human and mouse CREB-1 (cross-reacts with mouse, rat, human, bovine and porcine CREB-1 p43; dilution 1:250). The specificity of these antisera for porcine material and their optimal dilutions were determined previously (not shown). Visualization of substances was performed using secondary horseradish peroxidase-conjugated anti-rabbit or anti-mouse IgGs (Santa Cruz), SuperSignal chemiluminescent substrate and CL-X film (both from Pierce, Rockford, IL, USA). Medium incubated without cells, and samples subjected to all the reagents except primary antibody, were used as negative controls. The molecular weights of fractions were evaluated using a molecular weight calibration kit (14.4-94.0 kDa; Serva, Heidelberg, Germany).

\section{Immunocytochemical analysis}

The presence of Bax, PKA and CREB-1 in granulosa cells was demonstrated using immunocytochemistry (Osborn \& Isenberg 1994) as described previously (Sirotkin \& Makarevich 1999, Sirotkin et al. 2000) using primary rabbit or mouse antibodies as described above. Secondary polyclonal rabbit or goat IgGs, labeled with horseradish peroxidase (Santa Cruz; dilution 1:500) and 3-3' diaminobenzidine (DAB) reagent (Boehringer Mannheim $\mathrm{GmbH}$, Mannheim, Germany; 10\%) were used for the visualization of primary antibody. The activity and specificity of primary antibodies and the molecular weights of their ligands were confirmed prior to experiment by Western blotting (see above). Cells treated with secondary antibody and $\mathrm{DAB}$ but omitting the primary antibody, or with secondary antibody, $\mathrm{DAB}$ and control rabbit serum instead of primary antibody $(1: 100)$ were used as negative controls. The presence of immunoreactivity in the cells was determined by one observer using light microscopy. The percentage of stained cells and localization of antigens were determined in granulosa cells freshly isolated from follicles, whilst localization of antigens was additionally confirmed by inspection of pre-cultured (expanded) granulosa cells.

\section{Immunoassay}

Concentrations of progesterone, androstenedione, estradiol, oxytocin, inhibin A, inhibin B, IGF-I, TGF and IGFBP-3 were determined in 25-100 $\mu$ l incubation medium by RIAs or ELISAs, previously validated for use in culture medium.

Progesterone and androstenedione concentrations were determined using RIA kits from DSL (Webster, TX, USA). Estradiol was assayed using an RIA kit from BioChem Immuno Systems Italia S.p.A. (Rome, Italy). IGFBP-3 was assayed, after extraction, using an RIA kit from Mediagnost (Tuebingen, Germany). TGF-2 $\beta$ was assayed using ELISA kits from Bender Med Systems $\mathrm{GmbH}$ (Vienna, Austria). Inhibins A and B were assayed using ELISA kits from Serotec (Oxford, Oxon, UK). All assays were carried out according to the manufacturers' instructions. Concentrations of IGF-I were determined after extraction using an RIA as described previously (Makarevich \& Sirotkin 1999) and a rabbit antiserum kindly provided by Dr A F Parlow, National Hormone and Peptide Program, Harbor-UCLA Medical Center, Torrance, CA, USA). Oxytocin concentrations were measured by RIA as described previously (Kotwica \& Skarzynski 1993) using rabbit antiserum against oxytocin kindly provided by Dr G Kotwica, University of Agriculture and Technology, Olsztyn, Poland. All RIAs and IRMAs were validated for culture medium. The characteristics of these assays are presented in Table 1.

\section{Statistics}

Each experimental group was represented by four culture wells, each well containing three follicle halves. The data shown are the means of values obtained in three separate experiments performed on separate days using separate pools of follicles, each pool obtained from 20-40 animals. The samples of lysed cells from groups corresponding to the three experiments, taken prior to Western immunoblotting, were obtained together, whist RIA and immunocytochemical analyses were performed on each experiment separately. For immunocytochemical analysis, the proportions of cells containing specific immunoreactivity in each experiment were calculated on the basis of inspection of a minimum of 1000 cells per group. RIAs of each sample were performed in duplicate. In the RIAs, the values of blank controls were subtracted from the value determined in cell-conditioned medium so as to exclude any non-specific background. Rates of secretion were calculated per mg follicular tissue/day. Significant differences between the experiments were evaluated using 
Table 1 Characteristics of immunoassays used in experiments

\begin{tabular}{|c|c|c|c|c|}
\hline & $\begin{array}{l}\text { Specificity of assay } \\
\text { (cross-reactvity } \\
\text { of antiserum) }\end{array}$ & $\begin{array}{l}\text { Sensitivity of } \\
\text { assay } \\
(\mathrm{ng} / \mathrm{ml})\end{array}$ & $\begin{array}{l}\text { Intra-assay coefficient } \\
\text { of variation } \\
(\%)\end{array}$ & $\begin{array}{l}\text { Interassay coefficient } \\
\text { of variation } \\
(\%)\end{array}$ \\
\hline \multicolumn{5}{|l|}{ Assay } \\
\hline Androstenedione & $\begin{array}{l}0 \cdot 33 \% \text { to androsterone, } \\
0 \cdot 25 \% \text { to hydroxyprogesterone, } \\
0 \cdot 16 \% \text { to cortisone, } \\
<0 \cdot 09 \% \text { to dihydrotestosterone, progesterone, } \\
\text { cortisol, estone, cholesterol, estradiol, estriol }\end{array}$ & $0 \cdot 03$ & $<5 \cdot 8$ & $<9 \cdot 8$ \\
\hline Estradiol & $\begin{array}{l}0 \cdot 47 \% \text { to estriol, } 1 \cdot 77 \% \text { to estrone, } \\
<0 \cdot 0001 \% \text { to progesterone, androstenedione, } \\
\text { cortisol and estradiol metabolites }\end{array}$ & $0 \cdot 06$ & $<1 \cdot 0$ & $<2 \cdot 0$ \\
\hline Oxytocin & $\begin{array}{l}<0 \cdot 01 \% \text { to arg-vasopressin, lys-vasopressin, } \\
\text { arg-vasotocin, IGF-I, IGFBP-3, pGH, TPO }\end{array}$ & 0.0035 & $<9 \cdot 0$ & $<5 \cdot 0$ \\
\hline IGFBP-3 & $\begin{array}{l}<0 \cdot 001 \% \text { to IGFBP-I, IGFBP-2, IGFBP-4, IGF-I, } \\
\text { IGF-II, oxytocin }\end{array}$ & $0 \cdot 5$ & $<6 \cdot 2$ & $<8 \cdot 3$ \\
\hline TGF2 $\beta$ & $<0 \cdot 001 \%$ to humanTGF- $1 \beta$, TGF- $3 \beta$, oxytocin, TPO & $10 \cdot 0$ & $<10$ & $<10$ \\
\hline Inhibin A & $\begin{array}{l}<0 \cdot 01 \% \text { to inhibin } B \text {, pro- } \alpha \text { C subunit of inhibin A, } \\
\text { activins, oxytocin, TPO }\end{array}$ & $3 \cdot 9$ & $<10$ & $<10$ \\
\hline Inhibin B & $\begin{array}{l}<1 \% \text { to inhibin } A,<0 \cdot 01 \% \text { to pro- } \alpha \mathrm{C} \text { subunit of } \\
\text { inhibin } \mathrm{B} \text {, activins, oxytocin, TPO }\end{array}$ & $15 \cdot 6$ & $<7 \cdot 0$ & $<7 \cdot 0$ \\
\hline
\end{tabular}

two-way ANOVA. When effects of treatments were revealed in all three experiments, the data from the experimental and control groups were compared by Duncan's multiple range test. Differences from control at $P<0 \cdot 05$ were considered as significant.

\section{Results}

Results of SDS-PAGE and Western immunoblotting: effect of TPO on the presence of substances within ovarian follicles

Protein gel electrophoresis and Western immunoblotting (Fig. 1) demonstrated the presence of PCNA (the band at approximately $36 \mathrm{kDa}$ ), Bax (approximately $23 \mathrm{kDa}$ ), Cdc2/p34 (two subfractions approximately $34 \mathrm{kDa}$ ), two fractions of phosphotyrosine/TK (approximately 43 and $48 \mathrm{kDa}$ ), PKA (two bands at approximately $47 \mathrm{kDa}$ ) and CREB-1 (the band at approximately $43 \mathrm{kDa}$ ) in lysates of porcine ovarian follicles. Incubation of cells with TPO increased the expression of all the substances analyzed although responses varied: TPO increased the expression of PCNA, phosphotyrosine, PKA (at concentrations of 10 or $100 \mathrm{ng} / \mathrm{ml}$ ), Bax (at $1 \mathrm{ng} / \mathrm{ml}$ ), Cdc2/p34 (at all concentrations added) and CREB-1 (at $10 \mathrm{ng} / \mathrm{ml}$ ).
TPO was able to induce not only quantitative but also qualitative changes in the accumulation of some substances: when given at 10 or $100 \mathrm{ng} / \mathrm{ml}$, it induced the appearance of PCNA and of an additional (48 kDa) band of phosphotyrosine.

Results of immunocytochemical analysis: effect of TPO and of PKA blocker on the presence of substances within ovarian granulosa cells

Immunocytochemical analysis confirmed the presence of Bax, PKA and CREB in the porcine ovary. Bax was localized mainly in cytoplasm, PKA in both cytoplasm and nucleus, whilst small amounts of CREB were observed only in the nuclei of granulosa cells.

TPO, at concentrations of 1 or $10 \mathrm{ng} / \mathrm{ml}$ (but not at $100 \mathrm{ng} / \mathrm{ml}$ ) significantly increased the percentage of granulosa cells containing Bax (Fig. 2A). The low TPO concentration $(1 \mathrm{ng} / \mathrm{ml})$ significantly increased the proportion of PKA-positive cells, the middle concentration $(10 \mathrm{ng} / \mathrm{ml})$ did not change this index, whilst the high concentration $(100 \mathrm{ng} / \mathrm{ml})$ reduced it (Fig. 2B). The low TPO concentration did not affect the percentage of cells with CREB-1, but the higher concentrations significantly 
PCNA
36kDa

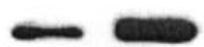

Bax
$23 k D a$

Cdc2/p34
$34 k D a$

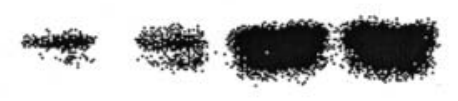

TK

$34 \mathrm{kDa}$

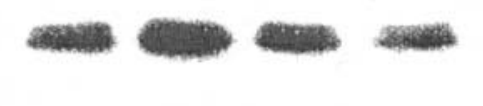

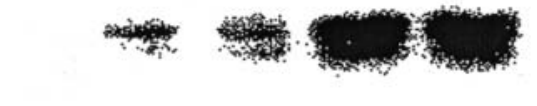

PKA

$47 \mathrm{kDa}$

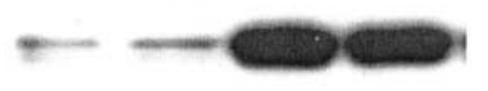

CREB-1

$43 \mathrm{kDa}$

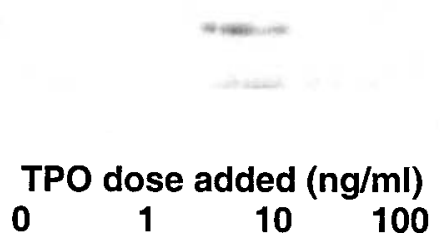

Figure 1 Effect of TPO on expression of PCNA, Bax, Cdc2/p34, TK (phosphotyrosine), PKA and CREB-1 identified using SDS-PAGE and Western immunoblotting in the lysate of porcine ovarian follicles cultured for 2 days in a serum-free medium. $\mathrm{kDa}$, approximate molecular mass of fractions.

increased expression of CREB in these cells (Fig. 2C). There was no marked influence of TPO on the localization of antigens within the cells.

The PKA blocker KT5720, when given alone, significantly reduced the proportion of granulosa cells with Bax (Fig. 2A) and increased the percentage of PKA- and CREB-positive cells (Fig. 2B and C). Furthermore, whilst

Figure 2 Effect of TPO $(0,1,10$ or $100 \mathrm{ng} / \mathrm{ml}$ medium) alone $(\bigcirc)$ and in combination with PKA inhibitor KT5720 $(1 \mu \mathrm{g} / \mathrm{ml}(\mathbf{)}))$ on the percentage of porcine granulosa cells containing (A) Bax, (B) PKA and (C) CREB-1 cultured for 2 days in a serum-free medium. Substances were identified using immunocytochemical methods. Values are means \pm S.E.M. ${ }^{*} P<0 \cdot 05$ compared with control (medium without TPO); ${ }^{a} P<0.05$ between corresponding TPO- and TPO plus KT5720-treated groups.
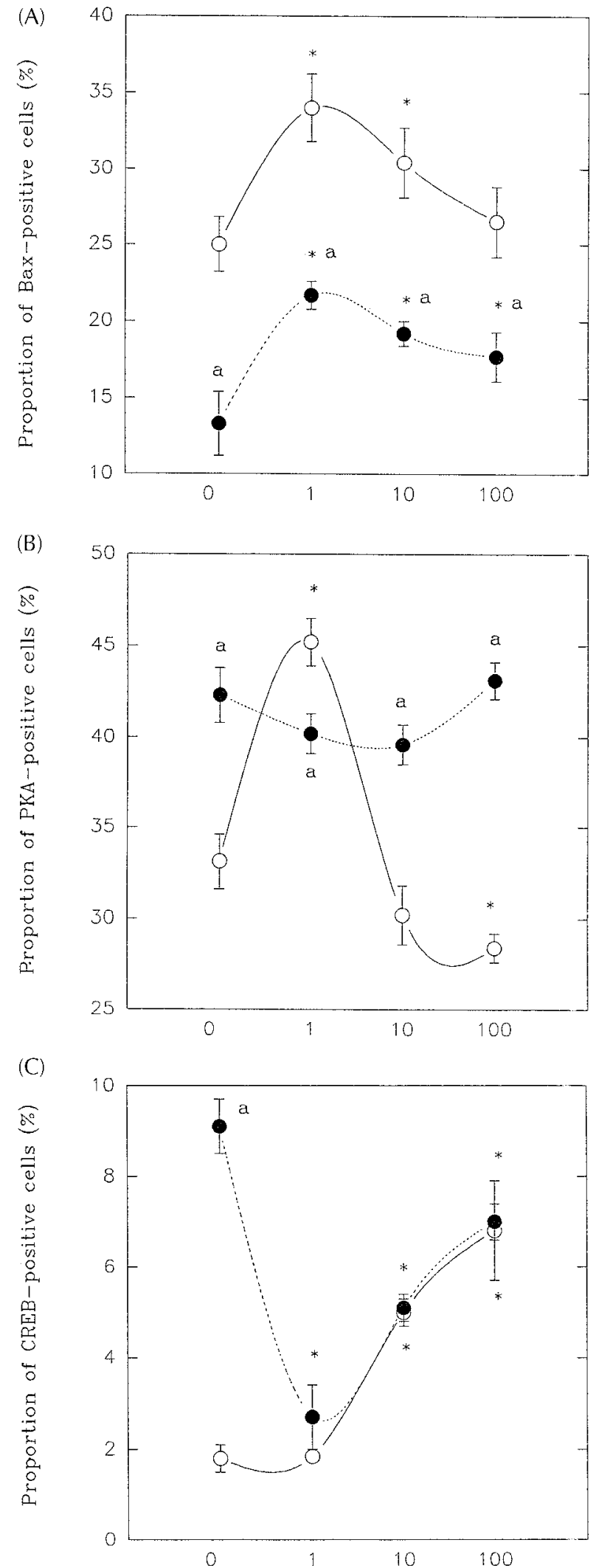

Journal of Endocrinology (2004) 183, 595-604

Downloaded from Bioscientifica.com at 04/26/2023 01:43:28PM 
(A)

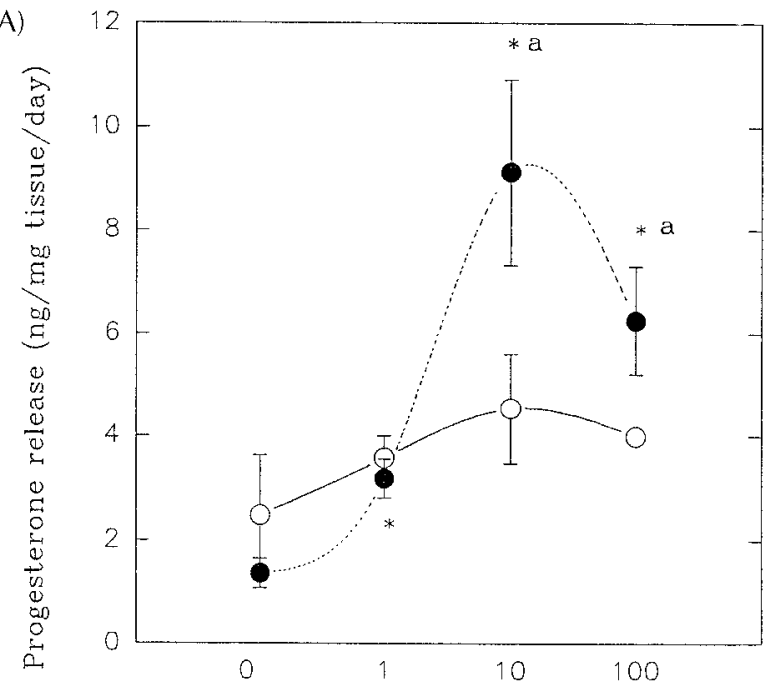

(C)

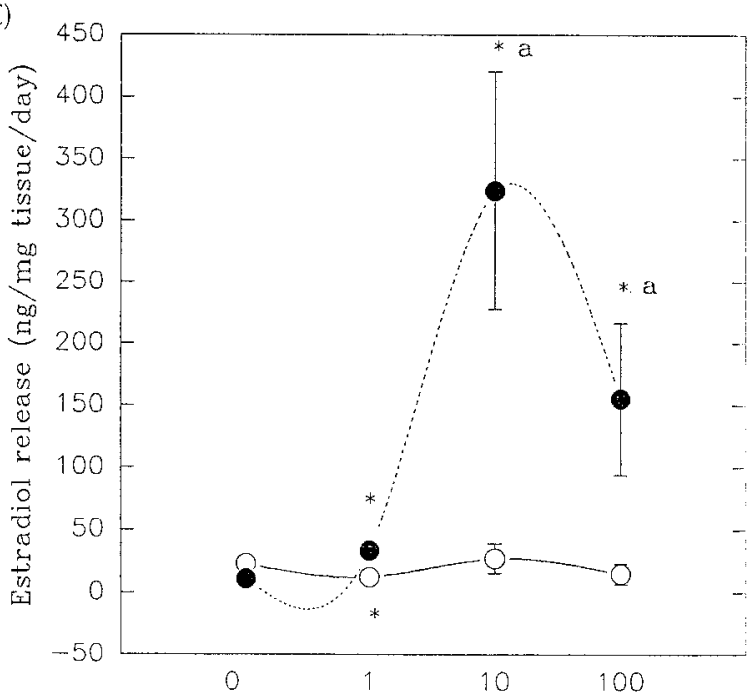

(E)

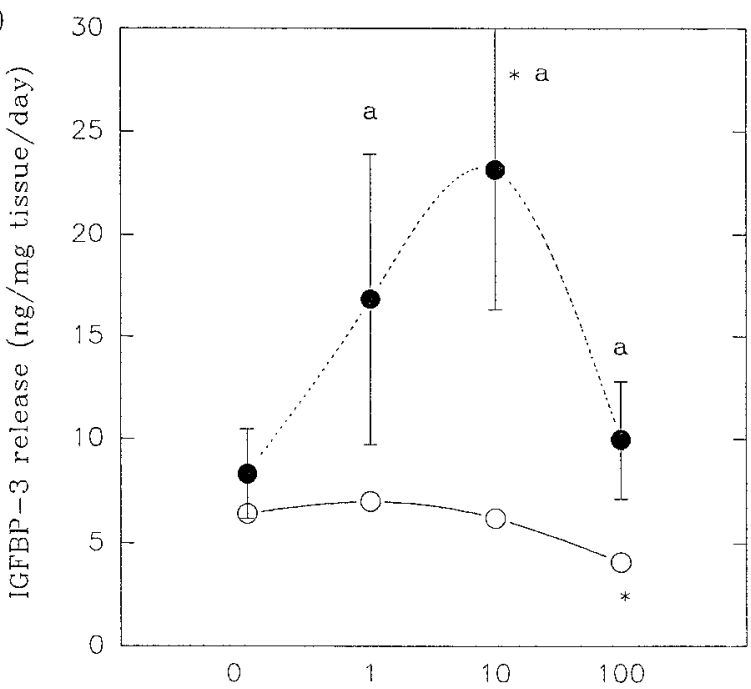

(B)

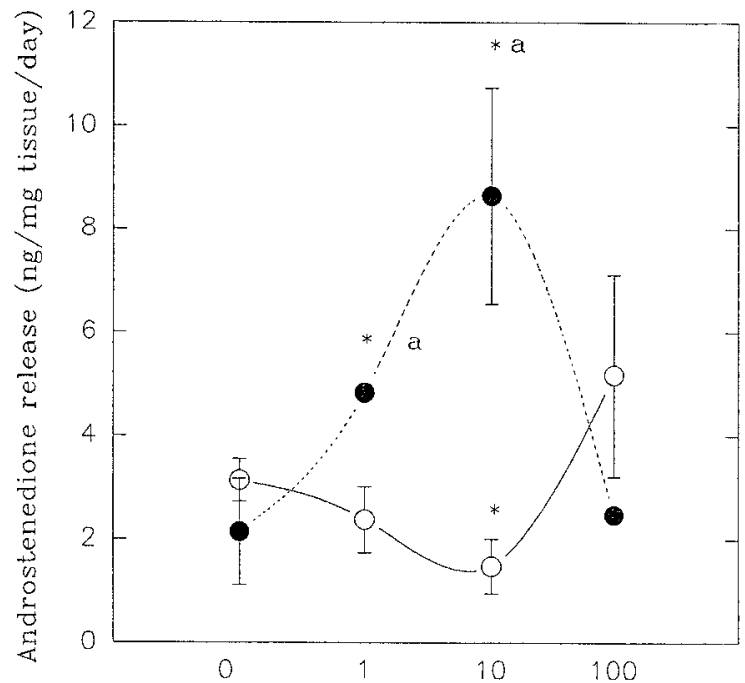

(D)

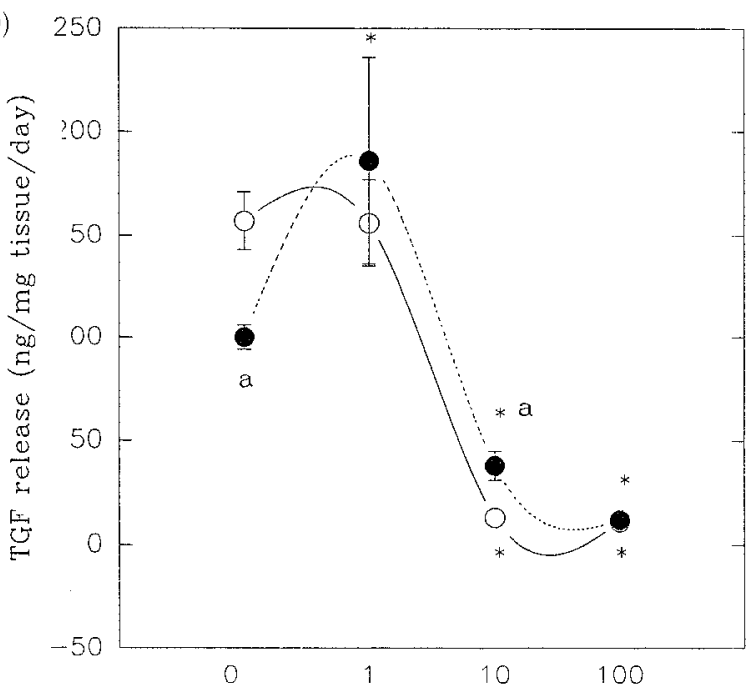

(F)

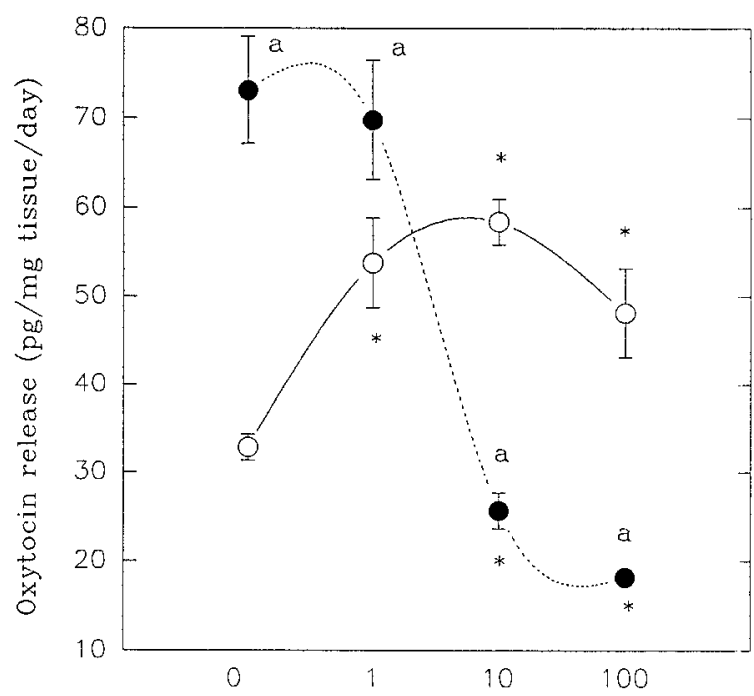



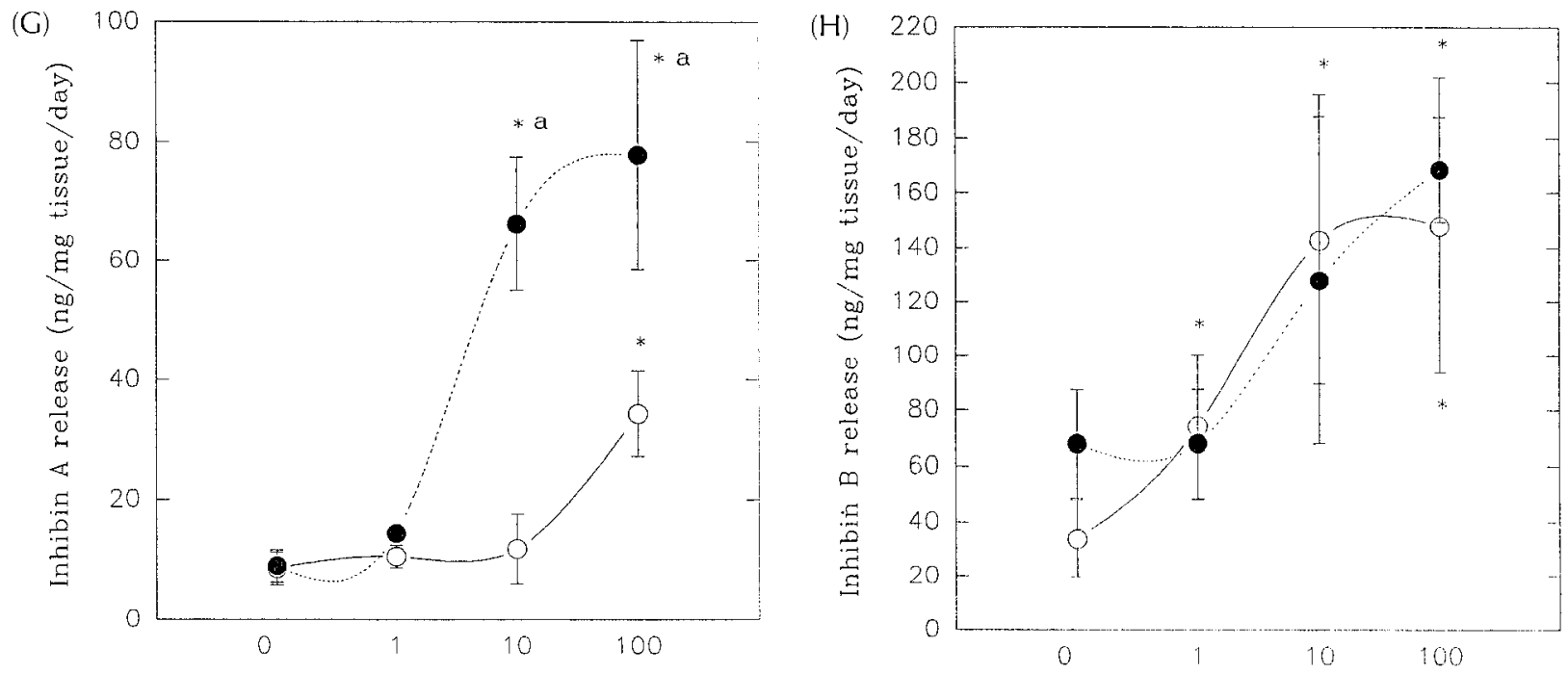

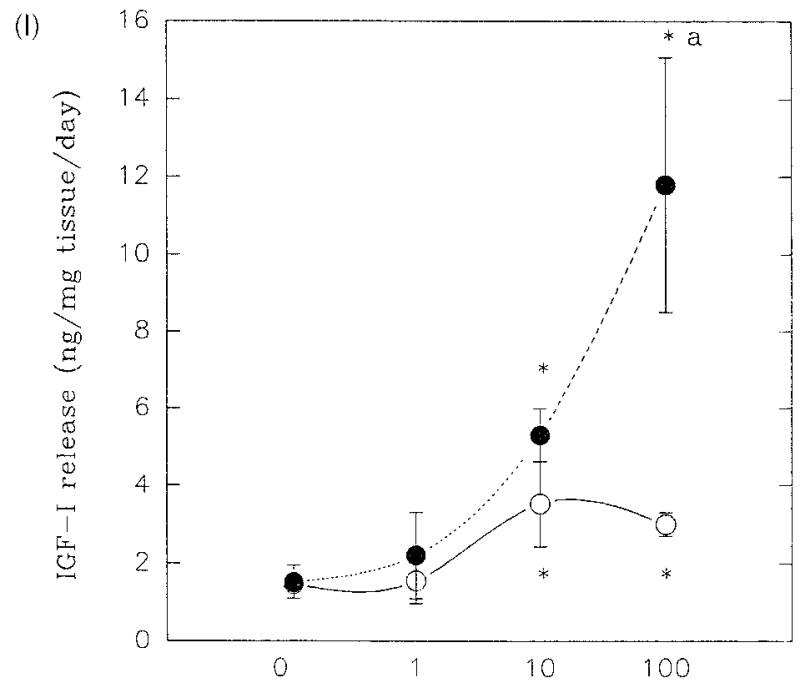

Figure 3 Effect of TPO $(0,1,10$ or $100 \mathrm{ng} / \mathrm{ml}$ medium) alone $(\mathrm{O})$ and in combination with PKA inhibitor $\mathrm{KT} 5720(1 \mu \mathrm{g} / \mathrm{ml}(\mathbf{O}))$ on $(\mathrm{A})$ progesterone, (B) androstenedione, (C) estradiol, (D) TGF, (E) IGFBP-3, (F) oxytocin, (G) inhibin A, (H) inhibin B and (I) IGF-I secretion by porcine ovarian follicles cultured for 2 days in a serum-free medium. Values are means \pm S.E.M. ${ }^{*} P<0 \cdot 05$ compared with control (medium without TPO); ${ }^{\text {a }}<0.05$ between corresponding TPO- and TPO plus KT5720-treated groups.

KT5720 did not substantially modify the pattern of the effect of TPO on Bax (Fig. 2A), it prevented its action on PKA (Fig. 2B) and reversed its effect on CREB (stimulation to inhibition; Fig. 2C).

Results of RIA and ELISA: effect of TPO and PKA blocker on secretion of substances by ovarian follicles

RIA and ELISA of ovarian follicle-conditioned medium demonstrated that porcine ovarian cells were able to secrete significant amounts of progesterone, androstenedione, oxytocin, inhibin A, inhibin B, IGF-I, IGFBP-3 and TGF-2 $\beta$ (Fig. 3). TPO did not affect progesterone (Fig. 3A) but inhibited androstenedione (at $10 \mathrm{ng} / \mathrm{ml}$; Fig. 3B), estradiol (at $1 \mathrm{ng} / \mathrm{ml}$; Fig. 3C), TGF-2 $\beta$ (at 10 or $100 \mathrm{ng} / \mathrm{ml}$; Fig. 3D) and IGFBP-3 (at $100 \mathrm{ng} / \mathrm{ml}$; Fig. 3E) secretion. On the other hand, TPO stimulated the secretion of oxytocin (at all concentrations; Fig. 3F), inhibin A (at $100 \mathrm{ng} / \mathrm{ml}$; Fig. 3G), inhibin B (at 10 or $100 \mathrm{ng} / \mathrm{ml}$; Fig. 3H) and IGF-I (at 10 or $100 \mathrm{ng} / \mathrm{ml}$; Fig. 3I).

The PKA blocker KT5720 $(1 \mu \mathrm{g} / \mathrm{ml})$, when given alone, did not influence progesterone, androstenedione, estradiol, IGFBP-3, inhibins A and B and IGF-I secretion, but was able to inhibit TGF-2 $\beta$ and stimulate oxytocin. Furthermore, when given together with TPO, it was able 
to prevent or even reverse the action of TPO on androstenedione (Fig. 3B), estradiol (Fig. 3C), IGFBP-3 (Fig. 3E), oxytocin (Fig. 3F) but not that on TGF-2 $\beta$ (Fig. 3D) or inhibin B (Fig. 3H). On the other hand, the addition of KT5720 augmented the effect of TPO on progesterone (Fig. 3A), inhibin A (Fig. 3G) and IGF-I (Fig. 3I).

\section{Discussion}

Our observations correspond, in general terms, with previous reports on the production of PCNA (Peng et al. 1998, Sirotkin et al. 2003), Cdc2/p34 (Shimada et al. 2001), TK (Okamura et al. 2001), PKA (Sirotkin et al. 2000, 2003), progesterone, androstenedione, estradiol, oxytocin, IGF-I, IGFBP-3 (Sirotkin et al. 1998, 2000, 2003), TGF-2 $\beta$ (May et al. 1996) and inhibins (Gutherie et al. 1997, Sirotkin et al. 2003) by porcine ovarian cells. This is, however, the first report of Bax and CREB in the porcine ovary. Immunocytochemical analysis showed that Bax, PKA and CREB can be produced by granulosa cells, whilst the exact source of other substances generated by ovarian follicles and determined by RIA and Western immunoblotting remains to be elucidated.

The two TK fractions with different molecular masses, detected by Western immunobloting, suggest the existence of at least two well-differentiated forms of TK within ovarian cells, possibly corresponding to receptor-bound and cytoplasmic TKs. The two subfractions of PKA shown by Western blotting may be due to the binding of antiserum to both regulatory and catalytic subunits of PKA. The presence of PKA in both cytoplasm and nuclei confirms previous evidence (Sassone-Corsi 1998) of the migration of the catalytic subunit of PKA from the cytoplasm to the nucleus to phosphorylate CREB and other transcription factors.

Our data are the first to demonstrate an influence of TPO on ovarian intracellular messengers. The stimulatory action of TPO on all intracellular substances studied was demonstrated using both immunoblotting and immunocytochemical methods, although some quantitative concentration-dependent differences were noted in the effects of TPO on granulosa cells (Fig. 2) and whole follicles (Fig. 1). They may be due to differing responses or sensitivities of granulosa and theca cells to TPO, or to some difference in the characteristics measured by these methods (Western analysis identifies the total amount of immunoreactive substance in the follicular wall, whereas immunocytochemistry allows an estimate of the percentage of granulosa cells containing the substance and its intracellular location). Nevertheless, the response of ovarian cells to TPO was demonstrated by all the methods used.

The TPO-induced accumulation of both PCNA (proliferation-associated antigen) and Bax (apoptosis- associated substance) within the cells suggests that TPO can stimulate both proliferation and apoptosis. Despite the general antagonism between the expression of proliferation and apoptosis in porcine ovary (Peng et al. 1998), these processes exhibit much similarity in terms of the expression and intracellular mechanisms (Pucci et al. 2000) which are regulated by TPO. Both the Trypan blue test and the presence of Bax indicated the presence of degenerated cells in the ovarian cell wall. It is possible that TPO can promote cell selection inducing proliferation of viable cells and apoptosis in non-viable cells. Nevertheless, the well-expressed differences in TPO action on PCNA and Bax (Fig. 1) suggest that TPO is primarily a proliferation- rather than an apoptosis-inducing substance.

The stimulatory effect of TPO on the expression of different protein kinases and transcription factors observed in our experiments may be indirect evidence that the effects of TPO on the ovary are mediated by PKA-, TKand $\mathrm{Cdc} 2 / \mathrm{p} 34-d e p e n d e n t$ intracellular mechanisms. Some of the observed changes could be primary, whilst other events could be secondary due to actions on other kinases or cross-talk between different intracellular signaling pathways. For example, TK can regulate MAPK (CarterSu et al. 2000, Okamura et al. 2001)-, cAMP/PKA (Makarevich et al. 1997)- and Cdc2/p34 (Jones \& Kazlauskas 2001)-dependent cascades. MAPKs are stimulators of Cdc2/p34 (Matsumura et al. 2000, Jones \& Kazlauskas 2001), and both PKA and MAPK are activators of CREB (Sassone-Corsi 1998).

This is the first report of an influence of TPO on ovarian secretory activity. Our RIA/ELISA data suggest the involvement of TPO in controlling ovarian steroid hormones (androstenedione, estradiol but not progesterone), peptide hormones (oxytocin, inhibins), growth factors (IGF-I, TGF-2 $\beta$ ) and growth factor-binding protein (IGFBP-3). These substances play an important role in controlling ovarian cell proliferation, apoptosis, ovarian folliculogenesis, oogenesis and tissue remodeling and may therefore be involved in the regulation of reproduction by TPO. The ability of TPO to induce ovarian cell proliferation, steroid and oxytocin secretion can be mediated by the stimulation of IGF-I and inhibition of IGFBP-3 secretion, which are potent regulators of the processes mentioned above (Spicer \& Echternkamp 1995, Sirotkin et al. 1998). The effects of TPO on steroid, IGF-I and IGFBP-3 production can be mediated by oxytocin (Sirotkin et al. 1998, 2003). The pro-apoptotic action of TPO may be due to its stimulation of inhibins, factors known to be associated with the atresia of ovarian follicles (Gutherie et al. 1997, Sirotkin et al. 2003). Figure 4 is a schematic diagram showing the possible physiological significance of TPO in control of ovarian functions.

The fine inter-relationships between TPO and different ovarian events require further study. Nevertheless, our present in vitro investigation offers the first evidence of involvement of TPO in the control of ovarian functions 


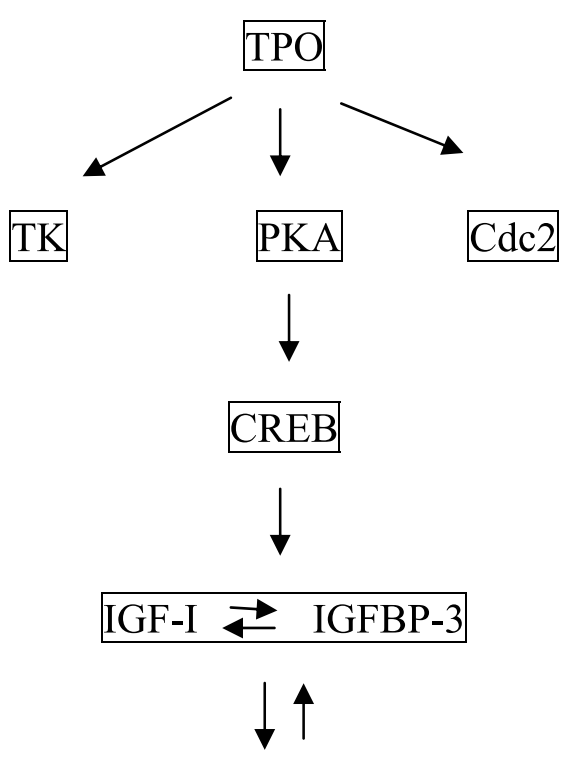

$\begin{array}{llll}\text { TGF- } \beta 2 & \text { OT } & \text { Steroids } & \text { Inhibins }\end{array}$

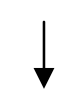

$\operatorname{Bax}$

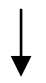

Apoptosis

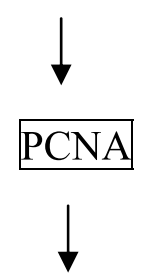

Proliferation
Figure 4 The possible physiological significance of TPO in control of ovarian functions. The flow diagram indicates possible inter-relationships between analysed ovarian substances and processes and the intracellular mechanisms that underline these inter-relationships.

(proliferation, apoptosis and secretion of hormones, growth factors and their binding proteins).

Our observations permit some conclusions concerning the ovarian role of PKA-dependent and other intracellular mechanisms and in the mediation of the effects of TPO. The ability of KT5720 to inhibit both the expression of Bax and the secretion of TGF-2 $\beta$, as well as to stimulate secretion of oxytocin, suggests that PKA-dependent intracellular mechanisms are involved in ovarian apoptosis. These observations confirm previous reports (Leung \& Steele 1992, Sirotkin \& Makarevich 1999, Sirotkin et al. 2000) of a role for PKA in ovarian apoptosis and secretory activity and in mediating the effects of hormones and growth factors on these functions. Furthermore, the observed increase in the percentage of cells containing PKA and CREB after KT5720 treatment suggests the existence of self-regulatory feedback mechanisms within the PKA/CREB axis such that blockade of the biological activity of PKA induces intracellular accumulation of PKA and its target transcription factor.

In our experiments, the PKA blocker not only affected basal ovarian functions but also substantially modified the effects of TPO on these functions. The ability of the PKA blocker to prevent or reverse the action of TPO on androstenedione, estradiol, IGFBP-3 and oxytocin demonstrates that TPO requires the activation of PKA. On the other hand, the ability of PKA blocker to augment the TPO effect on progesterone, inhibin A and IGF-I suggests that TPO stimulation of some ovarian secretions requires suppression rather than activation of PKA. Both sets of evidence suggest that the effect of TPO on the secretion of the majority of the ovarian substances studied is mediated by PKA-dependent intracellular mechanisms. On the other hand, the inability of KT5720 to modify the effect of TPO on TGF- $2 \beta$ and inhibin $\mathrm{B}$, together with the action of TPO on TK and $\mathrm{Cdc} 2 / \mathrm{p} 34$, suggest the potential involvement of protein kinases other than PKA.

The role of TPO in controlling reproduction, its targets and mechanisms of action within ovarian cells requires further elucidation. Nevertheless, the present studies show that TPO is a potent regulator of proliferation, apoptosis, secretion of steroid and peptide hormones, growth factors and growth factor-binding protein, as well as of the expression of some intracellular messengers in ovarian cells. Furthermore, this is the first demonstration of an important role for PKA in controlling these functions and in mediating the effects of TPO on ovarian cells.

\section{Acknowledgements}

We express our gratitude to Dr A F Parlow for kindly providing the antiserum against IGF-I, Dr G Kotwica for the gift of anti-oxytocin antiserum, $\mathrm{K}$ Tothová, $\mathrm{M}$ Blahová, Z Kuklova and B Ustianovska for technical assistance, and Dr M R Luck (University of Nottingham, Notttingham, Notts, UK) for editing the manuscript. The authors declare that there is no conflict of interest that would prejudice the impartiality of this scientific work.

\section{References}

Alexander WS 1999 Thrombopoietin. Growth Factors 17 13-24.

Carter-Su C, Rui L \& Herrington J 2000 Role of the tyrosine kinase JAK2 in signal transduction by growth hormone. Pediatric Nephrology 14 550-557.

Drachman JG, Rojnukarin P \& Kaushansky K 1999 Thrombopoietin signal transduction: studies from cell lines and primary cells. Methods 17 238-249.

Furunashi M, Miyabe Y \& Oda H 1999 A case of thrombopoietin-producing ovarian carcinoma confirmed by immunocytochemistry. Gynecological Oncology 74 278-281.

Gutherie HD, Ireland JL, Good TE \& Ireland JJ 1997 Expression of different molecular forms of inhibin in atretic and nonatretic follicles during the early luteal phase and altrenogest-synchronized follicular phase in pigs. Biology of Reproduction 56 870-877. 
Jones SM \& Kazlauskas A 2001 Growth factor-dependent signalling and cell cycle progression. FEBS Letters 490 110-116.

Kaszubska W, Zhang H, Patterson RL, Suhar TS, Uchic ME, Dickinson RW, Schaefer VG, Haasch D, Janis RS, DeVries PJ, Okasinski GF \& Meuth JL 2000 Expression, purification, and characterization of human recombinant thrombopoietin in Chinese hamster ovary cells. Protein Expression and Purification 18 213-220.

Kotwica J \& Skarzynski D 1993 Influence of oxytocin removal from the corpus luteum on secretory function and duration of the estrous cycle in cattle. Journal of Reproduction and Fertility 97 411-417.

Laemmli UK 1970 Cleavage and structure of proteins during the assembly of the head of bacteriophage T4. Nature 227 680-685.

Leung PCK \& Steele GL 1992 Intracellular signalling in the gonads. Endocrine Reviews 13 476-498.

Makarevich A \& Sirotkin A 1999 Development of a sensitive radioimmunoassay for IGF-I determination in samples from blood plasma and cell-conditioned medium. Veterinary Medicine 44 71-78.

Makarevich A, Sirotkin A, Taradajnik T \& Chrenek P 1997 Effects of genistein and lavendustin on reproductive processes in domestic animals in vitro. Journal of Steroid Biochemistry and Molecular Biology 63 329-337.

Makarevich AV, Sirotkin AV, Franek J, Kwon HB \& Bulla J 2004 The role of oxytocin, protein kinase A, and ERK-related MAP-kinase in the control of porcine ovarian follicle functions. Experimental and Clinical Endocrinology and Diabetes 112 108-114.

Matsumura I, Tanaka H, Kawasaki A, Odajima J, Daino H, Hashimoto K, Wakao H, Nakajama K, Kato T, Miyazaki H \& Kanakura Y 2000 Increased D-type cyclin expression together with decreased cdc2 activity confers megacaryocytic differentiation of a human thrombopoietin-dependent hematopoetic cell line. Journal of Biological Chemistry 275 5553-5559.

May JV, Stephenson LA, Turzcynski CJ, Fonh HW, Mau YH \& Davis JS 1996 Transforming growth factor beta expression in the porcine ovary: evidence that theca cells are the major secretory source during antral follicle development. Biology of Reproduction $\mathbf{5 4}$ 485-496.

Okamura Y, Myoumoto A, Manabe A, Tanaka A, Okamura H \& Fukumoto M 2001 Protein tyrosine kinase expression in the porcine ovary. Molecular Human Reproduction 7 723-729.

Osborn M \& Isenberg S 1994 Immunocytochemistry of frozen and paraffin tissue sections. In Cell Biology. A Laboratory Handbook, vol.2, pp 361-367. Ed JE Celis. New York: Academic Press.

Peng X, Maruo T, Matsuo H, Takekida S \& Deguchi J 1998 Serum deprivation-induced apoptosis in cultured porcine granulosa cells is characterized by increased expression of $\mathrm{p} 53$ protein, Fas antigen and Fas ligand and by decreased expression of PCNA. Endocrine Journal 45 247-253.
Pucci B, Kasten M \& Giordano A 2000 Cell cycle and apoptosis. Neoplasia 2 291-299.

Ryll T, Dutina G, Reyes A, Gunson J, Krummen L \& Etcheverry T 2000 Performance of small-scale CHO perfusion cultures using an acoustic cell filtration device for cell retention: characterization of separation efficiency and impact of perfusion on product quality. Biotechnology and Bioengineering 69 440-449.

Sassone-Corsi P 1998 Coupling gene expression to cAMP signalling: the role of CREB and CREM. International Journal of Biochemistry and Cell Biology 30 27-38.

Sauer M, Tausch S, Zieger M, Zintl F, Nowak G \& Kaufmann R 2001 Evidence for a novel thrombopoietin signalling event: activation of protein kinase $\mathrm{A}$ in human megacaryoblastic cmk cells. Cytokine 15 75-79.

Shimada M, Zeng WX \& Terada T 2001 Inhibition of phosphatidylinositol 3-kinase or mitogen-activated protein kinase leads to suppression of p34(cdc2) kinase activity and meiotic progression beyond the meiosis I stage in porcine oocytes surrounded with cumulus cells. Biology of Reproduction $\mathbf{6 5}$ $442-448$.

Sirotkin AV \& Makarevich AV 1999 GH regulates secretory activity and apoptosis in cultured bovine granulosa cells through the activation of the cAMP/protein kinase A system. Journal of Endocrinology 163 317-327.

Sirotkin AV, Makarevich AV, Kotwica J, Marnet P-G, Kwon HB \& Hetenyi L 1998 Isolated porcine ovarian follicles as a model for the study of hormone and growth factor action on ovarian secretory activity. Journal of Endocrinology 159 313-321.

Sirotkin AV, Makarevich AV, Pivko J, Kotwica J, Genieser H-G \& Bulla J 2000 Effect of cGMP analogues and protein kinase G blocker on secretory activity, apoptosis and the cAMP/protein kinase A system in porcine ovarian granulosa cells in vitro. Journal of Steroid Biochemistry and Molecular Biology 74 1-9.

Sirotkin AV, Florkovicova I, Makarevich AV, Schaeffer H-J, Kotwica J, Marnet P-G \& Sanislo P 2003 Oxytocin mediates some effects of insulin-like growth factor-I on porcine ovarian follicles. Journal of Reproduction and Development 49 141-149.

Spicer LJ \& Echternkamp SE 1995 The ovarian insulin-like growth factor system with an emphasis on domestic animals. Domestic Animal Endocrinology 12 223-245.

Wendling F \& Vainchenker W 1998 Thrombopoietin and its receptor. European Cytokine Network 9 221-231.

Received in final form 18 July 2004

Accepted 21 July 2004 